Apidologie, 1977, 8 (1) 19-24.

\title{
THE HYGROSCOPIC PROPERTIES OF DIFFERENT DILUTIONS OF HONEY
}

\author{
Keith M. DOULL and P. MEW \\ Waite Agricultural Research Institute \\ The University of Adelaide \\ Adelaide. S.A.
}

SUMMARY

The hygroscopie properties of different dilutions of honey at $34.5^{\circ} \mathrm{C}$ have been studied. Liquid honey with $82.5 \%$ solids was in equilibrium with water vapour in an atmosphere at $54.4 \%$ R.H. Only dilutions containing less than $40 \%$ solids maintained humidities close to the optimum range for hatching of eggs and survival of the young larvae of honeybees. It is argued that bees that deposit relatively dilute liquid in open brood cells are exhibiting a specific response to the humidities within the cells. This behaviour may be the means whereby bees control humidities in brood cells and is not necessarily related to their activities in controlling temperatures in the broodnest of the colony.

\section{INTRODUCTION}

Honeybees Apis mellifera L. deposit droplets or thin films of relatively dilute liquids in open brood cells. This activity has been assumed to be a component of the behaviour patterns exhibited by bees in maintaining optimum temperatures in the broodnest (LINDAUER, 1955).

Doull (1976) however, suggested that the deposition of liquids in cells that contain eggs might be an activity that would assist in the maintenance of optimum humidities for hatching of the eggs.

The atmosphere in the broodnest of a honeybee colony is always comparatively dry (Ribbands, 1953; Van Praagh, 1975). This is due in the main to the hygroscopic properties of honey and partially ripened nectar, for honey with $82.4 \%$ solids is in equilibrium with water vapour in an atmosphere of $58 \%$ R.H. at $21^{\circ} \mathrm{C}$ (Martin, 1939). Bees may deposit in brood cells, 
K. M. DOULL, P. MEW

liquids containing up to $73 \%$ sugars (LindaUer, loc. cit.) and it is unlikely that liquids of such concentrations would provide the $90-95 \%$ R.H. that is the optimum range of humidity for normal hatching of eggs of the honeybee (Doull, loc. cit.).

Hence it is reasonable to expect that there should be some activity that would enable the bees to counteract the relative dryness of the air in the broodnest. This paper examines the feasibility that the deposition of di.ute liquids in open brood cells might be this activity.

\section{METHODS}

Liquid honey with $82.5 \%$ solids was diluted with appropriate amounts of distilled water to provide the desired range of dilutions. The concentrations of solids in the various dilutions were measured with a hand-held Abbé refractometer.

All tests were carried out in an incubator at a constant temperature of $34.5{ }^{\circ} \mathrm{C}$. A series of desiccators (16 cm diameter) was used in the tests and the amounts of the test solutions were calculated to provide an evaporating surface of $122.7 \mathrm{~cm}^{2}$ in each desiccator. Five desiccators were used for each dilution and a direct-reading Lambrecht hair hygrometer was placed in each desiccator. Relative humidities were recorded 24 hours after each test was established.

After each dilution had been tested, the hygrometers were re-calibrated according to the manufacturer's instructions and were then checked against ambient humidities with a wet and dry bulb whirling psychrometer. Five desiccators and five hygrometers were used for each test dilution to allow for minor variations in readings of the individual hygrometers.

\section{RESULTS}

The results of the series of tests are presented in Fig. 1. Each point on the graph represents the mean of the five hygrometer readings for the dilution tested.

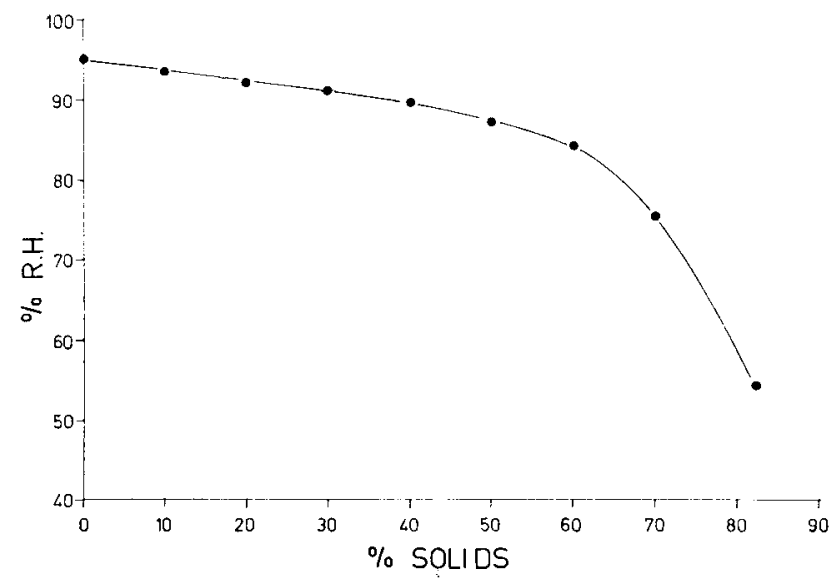

FIG. 1. - The hygroscopic properties of different dilutions of honey. Relative humidities obtained over various dilutions of honey at $34,5{ }^{\circ} \mathrm{C}$. 
As would be expected, liquid honey maintains a lower humidity at $34.5{ }^{\circ} \mathrm{C}$ than a honey of comparable sugar content at $21^{\circ} \mathrm{C}$. These results are compared in Fig. 2 with those presented in the senior author's previous paper (Doull, loc. cit.).

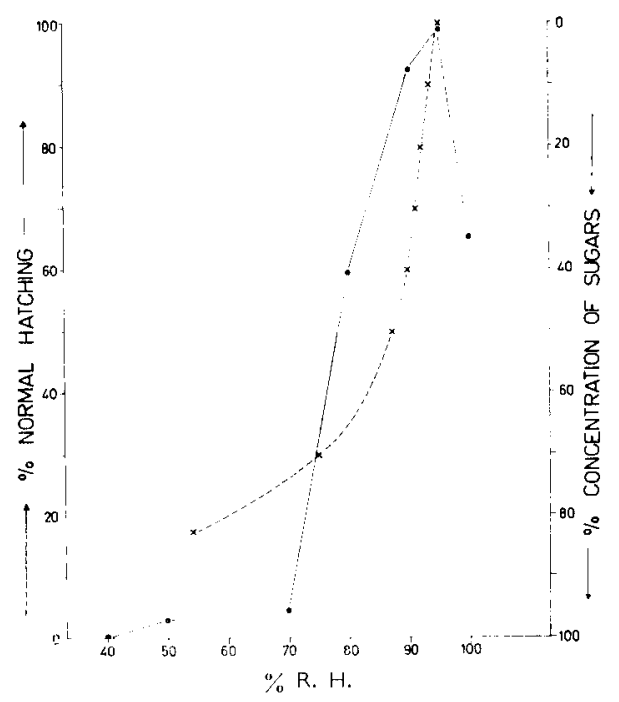

FIG. 2. - Relationships between hatching of the eggs of honeybees and the concentration of solids in liquids placed in open brood cells.

- $\%$ Normal hatching

$\times-\ldots \times \%$ Relative humidity

This comparison suggests that hatching of the eggs may be seriously impaired whenever bees deposit in the cells liquids that contain more than $40 \%$ solids.

\section{DISCUSSION}

These results support the contention that the deposition of dilute liquids in cells containing eggs is essential for the maintenance of optimum humidities for hatching of the eggs.

Yet bees also deposit liquid in cells containing young larvae. These larvae float on a pool of larval food containing 65-70\% water (HAYDAK, 1943) and it might appear that this activity could not serve any useful purpose. However, royal jelly with a moisture content comparable to that of larval food loses $40 \%$ of its water after 24 hours exposure to an atmosphere at $85 \%$ R.H. (SмIтH, 1959). The food of worker larvae too could then be expected to dry out quickly if it was directly exposed to the comparatively low humidities that normally prevail in the broodnest. This will be always 
possible because nurse bees place relatively large amounts of food alongside the larvae shortly after they emerge from the egg. Little or no food is provided on the second day of larval life (Lineburg, 1924). If this food should dry out the larvae would die. There can be little doubt that the drying out of food of young larvae, rather than high temperatures, was the cause of the loss of $70 \%$ of larvae in colonies denied access to water for two days in summer (LINDAUER, loc. cit.).

It is also relevant to this discussion to note that royal jelly loses only minimal amounts of water vapour when exposed to humidities in the range of $90-96 \%$ R.H. (SмгтH, loc. cit.). This is also the optimum range for normal hatching of the eggs.

Thus it is logical to suggest that there must be some means whereby bees in the broodnest may exert some control over humidities in open brood cells.

Water vapour is continually removed from the broodnest in the air that moves through the hive and in any case adult bees can withstand, and in fact seem to prefer, comparatively low humidities. It would then be a wasteful expenditure of the energy reserves of the colony if the bees attempted to maintain 90-95\% R.H. throughout the whole area of the broodnest. Indeed the hygroscopic properties of honey or of nectar ripened to contain more than $60 \%$ sugars would seem to make this an impossible task.

However, if this activity were to be confined to those cells that contain eggs and young larvae the colony would gain the greatest benefit for the least expenditure of energy.

The deposition of liquid in open brood cells is probably a normal activity of bees that frequent this area of the broodnest. Wherever possible they would deposit very dilute liquids obtained from incoming water collectors. These liquids would normally contain some sugars since they would be regurgitated from the honey stomachs of the bees.

In emergency situations the bees would use their crop contents for this purpose since these contain only $40 \%$ solids (LINdaUer, 1961). Fresh nectar containing 20-40\% solids would also serve in emergency until increased water collection could be established.

In LINDAUER's (1955) experiments on the responses of bees to sudden overheating, liquids containing up to $73 \%$ solids were deposited in open brood cells. This would have been detrimental to the brood since it would have increased the drying properties of the air in the cells. However, this behaviour of the bees also argues an innate stereotyped response to below optimum humidities in the cells, even though the effect of this behaviour would be the reverse of the desired efiect. 


\section{CONCLUSIONS}

The results of this study together with those of Doulu (loc. cit.) support the authors' contentions that there must be some biological process whereby bees may exert some control over humidities in the broodnest. It would be unnecessary, and virtually impossible, for them to maintain high humidities throughout the whole of the broodnest. The application of this process within the confined spaces of open brood cells--where the level of humidity is very critical-is an effective compromise. The evaporation of the water from these liquids might contribute to temperature control but this would be a minimal and secondary effect of this activity.

The results and discussion presented in this paper suggest that the assumption that honeybees do not actively control the humidity in the broodnest is incorrect and untenable.

They also further stress on the need to develop methods of supplying water inside hives when there is any danger that the bees will be unable to collect all the water that the colony needs to sustain optimum levels of broodrearing.

Eingegangen im November 1976.

Rę̧u pour publication en novembre 1976.

\section{RÉSUMÉ}

\section{LES PROPRIÉtÉs HYGROSCOPIQUES DE DIFFÉRENTES DILUTIONS DU MIEL}

On a dilué du miel liquide avec les quantités d'eau distillée nécessaires pour obtenir des solutions renfermant de 10 à $82,5 \%$ de solides et mesuré la fraction solide de chaque solution avec un réfractomètre à main Abbé.

On a testé chaque solution dans 5 dessicateurs et enregistré les hygrométries relatives à l'aide de 5 hygromètres Lambrecht à cheveu et lecture directe, maintenus dans une étuve à la température constante de 34,5 " $\mathrm{C}$.

Le miel liquide renfermant $82,5 \%$ de solides se trouve en équilibre avec la vapeur d'eau à $54,4 \%$ HR. Seules les solutions contenant au plus $40 \%$ de solides fournissent l'humidité optimale pour l'éclosion des æufs et la survie des jeunes larves.

Les résultats suggèrent que le dépôt dans les cellules de couvain non operculées de liquides relativement dilués est un moyen pour les abeilles de maintenir l'hygrométrie optimale dans les cellules du nid à couvain. Ils suggèrent également que cette activité est une réaction innée des abeilles aux hygrométries inférieures à l'optimum dans les cellules de couvain non operculées et n'est pas nécessairement en rapport avec la régulation thermique du nid à couvain. 


\section{ZUSAMMENFASSUNG}

\section{DIE HYGROSKOPISCHEN EIGENSCHAFTEN}

\section{VERSCHIEDENER HONIGLÖSUNGEN}

Um Lösungen mit 10-82,5\% festen Bestandteilen zu erzielen, wurde flüssiger Honig mit entsprechenden Mengen destillierten Wassers verdünnt. Das Verhältnis der festen Bestandteile der einzelnen Lösungen wurde mit dem Abbé-Handrefraktometer ermittelt.

Jede Lösung wurde in fünf Exsikkatoren untersucht und die relative Feuchte mit dem direkt anzeigenden Lambrecht-Haarhygrometer für jeden Exsikkator aufgezeichnet. Die Exsikkatoren standen bei konstanter Temperatur von 34,4 " $\mathrm{C}$ im Brutschrank.

Flüssiger Honig mit $82,5 \%$ festen Bestandteilen befand sich bei $54,5 \%$ rel.F. im Gleichgewicht mit dem Wasserdampf. Nur die Lösungen mit $40 \%$ oder weniger festen Bestandteilen ergaben optimale Feuchtigkeitswerte für das Schlüpfen der Eier und das Überleben junger Maden.

Aus den Untersuchungsergebnissen lässt sich schliessen, dass die Ablage verhältnismässig dünner Flïssigkeiten in die offenen Brutzellen ein Mittel ist, durch das die Bienen im Brutnest optimale Feuchtigkeit für die Brutzellen aufrechterhalten können.

Es wird ausserdem darauf hingewiesen, dass diese Tätigkeit die angeborene Reaktion der Biene auf nicht optimale Feuchtigkeitswerte in offenen Brutzellen ist und nicht unbedingt mit ihrer Tätigkeit der Temperaturkontrolle des Brutnestes zusammenhängt.

\section{REFERENCES}

DoulL K. M., 1976, The effects of different humidities on the hatching of honeybee eggs. Apidologie. $7: 61-66$.

HaydaK M. H., 1943, Larval food and development of castes in the honeybee. J. Econ. Ent. $36: 778-792$.

Martin E. C., 1939, The hygroscopic properties of honey. J. Econ. Ent. 32 : 660-663.

LiNDAUER M., 1955, The water economy and temperature regulation of the honeybee colony. Bee World. 6 : 62-72, 81-92, 105-111.

Lindauer M., 1961, Communication Among Social Insects. Harvard University Press, Cambridge. Mass. U.S.A.

Lineburg B., 1924, The feeding of honeybee larvae. Bull. U.S. Dept. Agric. No. 1222 : 25-37.

PARK O. W., 1925, The storing and ripening of honey by honeybees. J. Econ. Ent. $18:$ 405-410.

Ribbands R., 1953, The Behaviour and Social Life of Honeybees. Bee Research Association, London, England.

Sмгтн M, V., 1959, Queen differentiation and biological testing of royal jelly. Cornell University, Memoir No. 356.

Van Praagh J. P., 1975, Humidity within the beehive and broodrearing by the honeybee (Apis mellifera L.) in a flight room. Apidologie. 6 : 283-293. 